\title{
Ferrocenyl-substituted tetrahydrothiophenes via formal [3 + 2]-cycloaddition reactions of ferrocenyl thioketones with donor-acceptor cyclopropanes
}

\author{
Grzegorz Mlostoń ${ }^{* 1}$, Mateusz Kowalczyk ${ }^{1,2}$, André U. Augustin ${ }^{3}$, Peter G. Jones ${ }^{4}$ \\ and Daniel B. Werz ${ }^{*}$
}

\section{Full Research Paper}

\section{Address:}

${ }^{1}$ University of Łódź, Department of Organic \& Applied Chemistry,

Tamka 12, 91-403 Łódź, Poland, ${ }^{2}$ University of Łódź, The

Bio-Med-Chem Doctoral School of the University of Lodz and Lodz Instituties of the Polish Academy of Sciences, ${ }^{3}$ Technische Universität

Braunschweig, Institute of Organic Chemistry, Hagenring 30, 38106

Braunschweig, Germany, and ${ }^{4}$ Technische Universität Braunschweig,

Institute of Inorganic and Analytical Chemistry, Hagenring 30, 38106

Braunschweig, Germany

Email:

Grzegorz Mlostoń - grzegorz.mloston@chemia.uni.lodz.pl;

Daniel B. Werz* - d.werz@tu-braunschweig.de

* Corresponding author

Keywords:

[3 + 2]-cycloaddition reactions; donor-acceptor cyclopropanes;

ferrocenyl thioketones; sulfur heterocycles; tetrahydrothiophenes

\author{
Beilstein J. Org. Chem. 2020, 16, 1288-1295. \\ doi:10.3762/bjoc.16.109 \\ Received: 04 April 2020 \\ Accepted: 27 May 2020 \\ Published: 10 June 2020 \\ In Memoriam of Rolf Huisgen (München) 1920-2020
}

Associate Editor: D. Y.-K. Chen

(c) 2020 Mlostoń et al.; licensee Beilstein-Institut.

License and terms: see end of document.

\begin{abstract}
Ferrocenyl thioketones reacted with donor-acceptor cyclopropanes in dichloromethane at room temperature in the presence of catalytic amounts of $\mathrm{Sc}(\mathrm{OTf})_{3}$ yielding tetrahydrothiophene derivatives, products of formal [3+2]-cycloaddition reactions, in moderate to high yields. In all studied cases, dimethyl 2-arylcyclopropane dicarboxylates reacted with the corresponding aryl ferrocenyl thioketones in a completely diastereoselective manner to form single products in which (C-2)-Ar and (C-5)-ferrocenyl groups were oriented in a cis-fashion. In contrast, the same cyclopropanes underwent reaction with alkyl ferrocenyl thioketones to form nearly equal amounts of both diastereoisomeric tetrahydrothiophenes. A low selectivity was also observed in the reaction of a 2-phthalimide-derived cyclopropane with ferrocenyl phenyl thioketone.
\end{abstract}

\section{Introduction}

Functionalized tetrahydrothiophenes constitute an important group of five-membered sulfur heterocycles; many of them, both chiral and achiral, with biotin as the best-known representative, form the key motif in numerous compounds of great practical importance [1,2]. The development of chemo- and diastereoselective syntheses for these compounds is thus a challenging problem. An elegant and highly efficient method for the construction of the tetrahydrothiophene ring is based on 1,3- 
dipolar cycloadditions of in-situ-generated thiocarbonyl $S$-methanides (thiocarbonyl ylides) with electron-deficient ethylenic dipolarophiles. This method was extensively developed by Huisgen and co-workers in the 1980s [3-5]. In the course of these studies, a non-orthodox stepwise mechanism of the 1,3-dipolar cycloaddition was established by experiments performed with the sterically crowded thiocarbonyl $S$-methanide 1, derived from 2,2,4,4-tetramethyl-3-thioxocyclobutanone and extremely electron-deficient ethylenes $\mathbf{2}$ such as $(E)$ - and $(Z)$-dialkyl dicyanobutenoates $\left(\mathrm{R}=\mathrm{CO}_{2} \mathrm{Me}\right)[6]$, tetracyanoethylene $(\mathrm{R}=\mathrm{CN})$ [7] or $(E)$ - and $(Z)$-1,2-bis(trifluoromethyl)ethylene-1,2-dicarbonitrile $\left(\mathrm{R}=\mathrm{CF}_{3}\right)$ [8]. Both five-membered spirotetrahydrothiophenes 3 and seven-membered $S, N$-heterocycles (ketene imines) 4 were observed in the course of these reactions (Scheme 1). The latter products were trapped with suitable nucleophiles $\left(\mathrm{R}=\mathrm{CO}_{2} \mathrm{Me}\right)$ or even isolated and identified by means of spectroscopic methods $\left(\mathrm{R}=\mathrm{CF}_{3}\right)$.

In a recent work, an alternative, efficient and useful method for the synthesis of highly functionalized tetrahydrothiophenes of type 6 was reported [9] (Scheme 2). Under Lewis acid catalysis, formal $[3+2]$-cycloadditions of aromatic and cycloaliphatic thioketones (also thionoesters) with donor-acceptor cyclopropanes 5 (D-A cyclopropanes) were realized.

In contrast, thiochalcones $(\alpha, \beta$-unsaturated aromatic thioketones) were shown to react under similar conditions with cyclopropanes 5 yielding exclusively seven-membered tetrahydrothiepines 7 as products of the formal [4+3]-cycloaddition [10] (Scheme 2).

In a series of our recent publications, ferrocenyl/aryl and ferrocenyl/alkyl thioketones were demonstrated to be attractive substrates for the preparation of six- and five-membered sulfur heterocycles via [4+2]- and [3+2]-cycloadditions, respectively [11-15]. Notably, in contrast to aryl/alkyl thioketones (e.g., thioacetophenone), their ferrocenyl analogs of type 8 (e.g.,

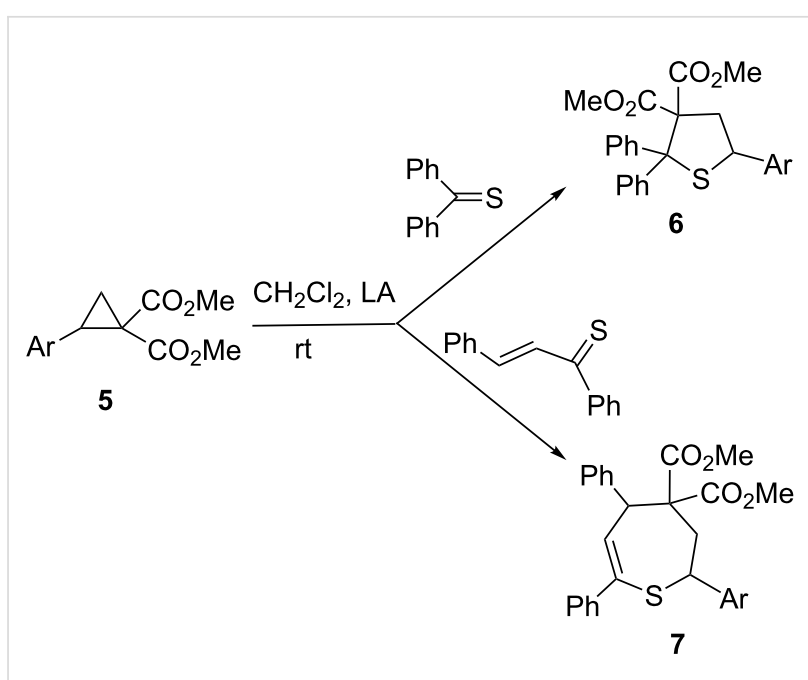

Scheme 2: Formal [3 + 2]-cycloadditions of thioketones and [4 + 3]-cycloadditions of thiochalcones with donor-acceptor cyclopropanes 5 leading to tetrahydrothiophenes 6 and tetrahydrothiepines 7 , respectively.

ferrocenyl phenyl thioketone (8a), diferrocenyl thioketone (8b), and ferrocenyl methyl thioketone $(\mathbf{8 c})$ ) were stable compounds at ambient conditions and could be used with no special precautions. In general, ferrocene has been considered as an 'exceptional compound' [16,17] and in our hands ferrocenyl-functionalized sulfur heterocycles, e.g., thiiranes and 1,3-dithiolanes, have found applications for the synthesis of compounds relevant for medicinal [18] and materials chemistry, and electrochemical studies [19].

In continuation of our studies on organic sulfur compounds and the mechanisms of their reactions, the main goal of the present work was the examination of the formal $[3+2]$-cycloaddition reactions of ferrocenyl-substituted thioketones 8 with D-A cyclopropanes $\mathbf{5}$, aimed at the synthesis of hitherto unreported, ferrocenyl-substituted tetrahydrothiophene dicarboxylates (thiolanes) of type 9.

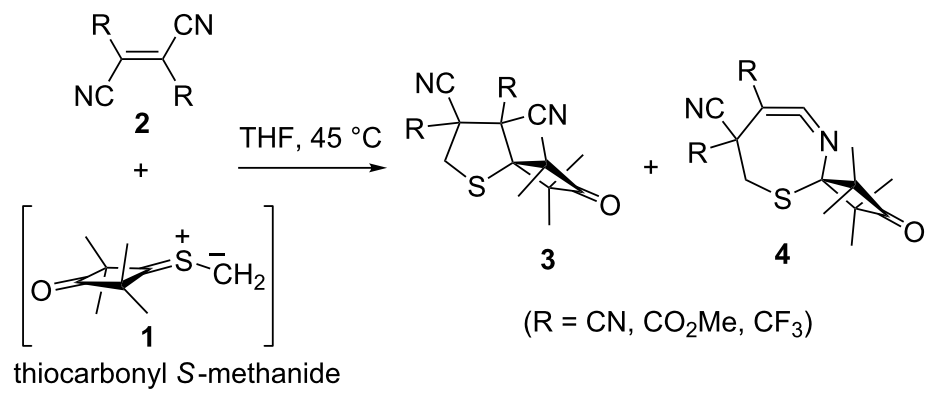

Scheme 1: Synthesis of spirotetrahydrothiophenes 3 via non-concerted [3+2]-cycloadditions of thiocarbonyl ylide 1 with electron-deficient ethylenes 2. Cyclic ketene imines 4 are also formed as products of formal [ $4+3]$-cycloadditions. 


\section{Results and Discussion}

In analogy to experiments described in our earlier publication [9], the test reaction was performed with dimethyl 2-phenylcyclopropane dicarboxylate (5a) and ferrocenyl phenyl thioketone (8a) in $\mathrm{CH}_{2} \mathrm{Cl}_{2}$ at room temperature using aluminum chloride $\left(\mathrm{AlCl}_{3}\right)$ as a catalyst. The reaction was monitored by TLC, and was shown to be complete after $1 \mathrm{~h}$. The crude reaction mixture was examined by ${ }^{1} \mathrm{H}$ NMR, revealing the formation of a single product with characteristic signals of both $\mathrm{CO}_{2} \mathrm{Me}$ groups located at 3.38 and $3.81 \mathrm{ppm}$. After chromatographic separation the expected tetrahydrothiophene $9 \mathbf{a}$ was isolated in only $23 \%$ yield. As the next model substrate, the sterically crowded diferrocenyl thioketone $(\mathbf{8 b})$ was tested as a structural analog of thiobenzophenone, which was widely applied in studies involving aromatic thioketones [3-5]. However, in contrast to $\mathbf{8 a}$, the reaction of $\mathbf{8 b}$ with $\mathbf{5 a}$ was unsuccessful. This observation prompted us to replace $\mathrm{AlCl}_{3}$ by scandium triflate
$\left(\mathrm{Sc}(\mathrm{OTf})_{3}\right)$, which is also known to be an efficient catalyst in various reactions of $\mathrm{D}-\mathrm{A}$ cyclopropanes $[9,10,20]$. This time, the reaction was complete after $1 \mathrm{~h}$ and the expected 2,2-diferrocenyl-substituted tetrahydrothiophene $\mathbf{9 b}$ was isolated chromatographically in about $28 \%$ yield (Scheme 3 , Table 1 ). This experiment was successfully repeated, again using $\mathrm{Sc}(\mathrm{OTf})_{3}$ instead of $\mathrm{AlCl}_{3}$, in further experiments of ferrocenyl thioketones 8 with differently substituted cyclopropanes 5. Again using $\mathrm{Sc}(\mathrm{OTf})_{3}$, we repeated the experiment with $\mathbf{8 a}$, which this time led to the isolation of 9a in an excellent yield of $98 \%$ (Table 1).

In analogy to 8a, the similarly substituted ferrocenyl ( $\beta$-naphthyl) thioketone $(\mathbf{8 c})$ reacted with $\mathbf{5 a}$ in a diastereoselective manner yielding the expected product $9 \mathrm{c}$ in good yield $(65 \%)$ as the sole isolated product. Notably, in all reactions performed with aryl-substituted cyclopropanes $\mathbf{5 a}-\mathbf{f}$ and with thioketones<smiles>COC(=O)C1(C(O)O[Na])CC1[Al]</smiles>

$5 a-9$

$\mathrm{Ar}=\mathbf{a}: \mathrm{Ph} ; \mathbf{b}: \beta-\mathrm{Naphthyl} ;$

c: $4-\mathrm{Me}-\mathrm{C}_{6} \mathrm{H}_{4}$;

d: $4-\mathrm{MeO}-\mathrm{C}_{6} \mathrm{H}_{4}$

e: $4-\mathrm{Br}-\mathrm{C}_{6} \mathrm{H}_{4}$;

f: $4-\mathrm{CF}_{3}-\mathrm{C}_{6} \mathrm{H}_{4}$;

g: 1-Phthalimid-1-yl
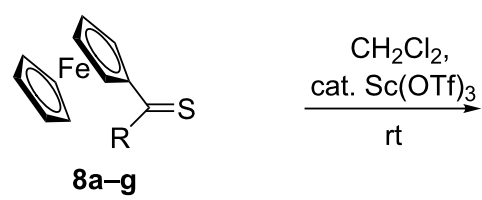

$\mathrm{R}=\mathbf{a}: \mathrm{Ph} ; \mathbf{b}: \mathrm{Fc}$

c: $\beta$-Naphthyl;

d: $\mathrm{Me}$;

e: $n$-Pr;

f: Thien-2-yl;

g: Fur-2-yl

Scheme 3: Formal [3 + 2]-cycloadditions of dimethyl 2-substituted cyclopropane-1,1-dicarboxylates $\mathbf{5 a - g}$ with ferrocenyl thioketones $\mathbf{8 a - g}$, leading to dimethyl tetrahydrothiophene 3,3-dicarboxylates $9 \mathbf{a}-\mathbf{n}$ (Table 1).

Table 1: Ferrocenyl-substituted tetrahydrothiophenes $\mathbf{9 a}-\mathbf{n}$ obtained in reactions of D-A cyclopropanes $\mathbf{5 a} \mathbf{a}$ with ferrocenyl thioketones $8 \mathbf{a}-\mathbf{g}$ catalyzed with $\mathrm{Sc}(\mathrm{OTf})_{3}$

\begin{tabular}{|c|c|c|c|c|}
\hline $\begin{array}{c}\text { compound } \\
9\end{array}$ & $\begin{array}{c}\text { substituent } \\
\mathrm{Ar}\end{array}$ & $\begin{array}{c}\text { substituent } \\
R\end{array}$ & ratio of diastereoisomers & yield of isolated products (\%) \\
\hline $\mathbf{a}$ & $\mathrm{Ph}$ & $\mathrm{Ph}$ & 100: 0 & 98 \\
\hline b & $\mathrm{Ph}$ & $\mathrm{Fc}^{\mathrm{a}}$ & - & 28 \\
\hline c & $\mathrm{Ph}$ & $\beta$-naphthyl & $100: 0$ & 65 \\
\hline d & $\mathrm{Ph}$ & $\mathrm{Me}$ & $55: 45$ & 98 \\
\hline e & $\mathrm{Ph}$ & $n-P r$ & $52: 48$ & 97 \\
\hline $\mathbf{f}$ & $\beta$-naphthyl & $\mathrm{Ph}$ & $100: 0$ & 30 \\
\hline $\mathbf{g}$ & $\beta$-naphthyl & $\beta$-naphthyl & $100: 0$ & 31 \\
\hline h & $4-\mathrm{Me}-\mathrm{C}_{6} \mathrm{H}_{4}$ & $\mathrm{Ph}$ & $100: 0$ & 85 \\
\hline i & $4-\mathrm{MeO}-\mathrm{C}_{6} \mathrm{H}_{4}$ & $\mathrm{Ph}$ & $100: 0$ & 79 \\
\hline $\mathbf{j}$ & $4-\mathrm{Br}-\mathrm{C}_{6} \mathrm{H}_{4}$ & $\mathrm{Ph}$ & $100: 0$ & 93 \\
\hline $\mathbf{k}$ & $4-\mathrm{CF}_{3}-\mathrm{C}_{6} \mathrm{H}_{4}$ & $\mathrm{Ph}$ & $100: 0$ & 95 \\
\hline I & $\mathrm{Ph}$ & thien-2-yl & $100: 0$ & 58 \\
\hline $\mathbf{m}$ & $\mathrm{Ph}$ & fur-2-yl & $60: 40$ & 96 \\
\hline $\mathbf{n}$ & phthalimid-1-yl & $\mathrm{Ph}$ & $60: 40$ & 34 \\
\hline
\end{tabular}

${ }^{a} \mathrm{Fc}=$ ferrocenyl. 
$\mathbf{8 a}, \mathbf{c}, \mathbf{f}$, the desired tetrahydrothiophenes $9 \mathbf{a}, \mathbf{c}, \mathbf{f}-\mathbf{l}$ were formed with complete diastereoselectivity, leading to a single isomer. In order to establish the structure of the isomers, a single crystal obtained for compound 9c was studied by X-ray diffraction analysis which showed, that the $\mathrm{Ph}(\mathrm{C}-2)$ group and $\mathrm{Fc}(\mathrm{C}-5)$ substituent were mutually cis-oriented (Figure 1). Tentatively, the same configuration was also attributed to all tetrahydrothiophenes $\mathbf{9 a}, \mathbf{f}-\mathbf{l}$ that were formed as single isomers (Table 1).

However, the diastereoselectivity changed in reactions that were conducted with alkyl ferrocenyl thioketones $8 \mathbf{d}-\mathbf{e}$ with $\mathbf{5 a}$ Thus, the reaction with $\mathbf{8 d}$ led to a 55:45 mixture of two isomeric products in nearly quantitative yield (98\%). Subsequently, they were carefully separated by preparative thin layer chromatography (PTC) on silica using a mixture of petroleum ether and ethyl acetate as an eluent. The less polar fraction formed the major product and the slightly more polar one was isolated and identified as the minor isomer of 9d. In the course of crystallization from hexane the less polar fraction gave single crystals suitable for the X-ray diffraction analysis, which unambiguously confirmed that in this molecule the $\mathrm{Ph}(\mathrm{C}-5)$ and $\mathrm{Fc}(\mathrm{C}-2)$ groups were trans-oriented and for that reason, this isomer was described as trans-9d (Figure 1).

Analogously, the reaction of ferrocenyl $n$-propyl thioketone $(\mathbf{8 e})$ with 5a led to a 52:48 mixture of trans-and cis-isomers of 9e, which were isolated in a total yield of $97 \%$ and identified without further separation. Moreover, a mixture of nearly equal amounts of isomeric trans-9m and cis-9m was also observed in the reaction of $\mathbf{5 a}$ with ferrocenyl fur-2-yl thioketone $(\mathbf{8 g})$. The reaction of the phthalimide-derived cyclopropane $\mathbf{5 g}$ with thioketone 8a led to a 4:1 mixture of both isomers cis- and trans-9n. Based on these observations it was difficult to explain the complete diastereoselectivity of tetrahydrothiophene formation observed in the reactions of aryl ferrocenyl-substituted thioketones 8a,c,f with cyclopropanes $\mathbf{5 a - f}$ bearing aryl groups. Tentatively, a repulsive interaction of aryl groups rather than steric hindrance of the bulky ferrocenyl unit could be postulated. Remarkably, ferrocenyl fur-2-yl thioketone $(\mathbf{8 g})$ was an exception and delivered a 60:40 mixture of trans- and cis-9m.

The mechanistic interpretation of the efficient, formal $[3+$ 2]-cycloadditions of D-A cyclopropanes 5 with ferrocenyl thioketones $\mathbf{8}$ in the presence of a Lewis acid was based on the assumption that the coordination of the catalyst by two ester groups activated the cyclopropane ring and allowed a nucleophilic attack of the $\mathrm{C}=\mathrm{S}$ group on the benzylic position of the cyclopropane derivative (Scheme 4).

The subsequent ring-closure of the zwitterionic intermediate $\mathbf{1 0}$ led to the formation of the tetrahydrothiophene derivative $\mathbf{9}$. This process formally resembled the $[3+2]$-cycloadditions of thiocarbonyl $S$-methanides with an activated C-C double bond, which also led to tetrahydrothiophenes [6-8]. Nevertheless, the key step involved the formation of the reactive, zwitterionic intermediate 10. It seemed that repulsive interactions of the aryl groups Ar (from cyclopropane 5) and R (from thioketone 8) controlled the diastereoselective ring-closure to the five-membered ring leading in these cases to the formation of $\mathrm{cis}_{\mathbf{-}} \mathbf{9}$ (Ar to $\mathrm{Fc}$ ) as a single isomer. A similar reaction pathway with a zwitterionic intermediate analogous to $\mathbf{1 0}$, generated in the presence of a Lewis acid, was proposed for the reaction of cycloaliphatic
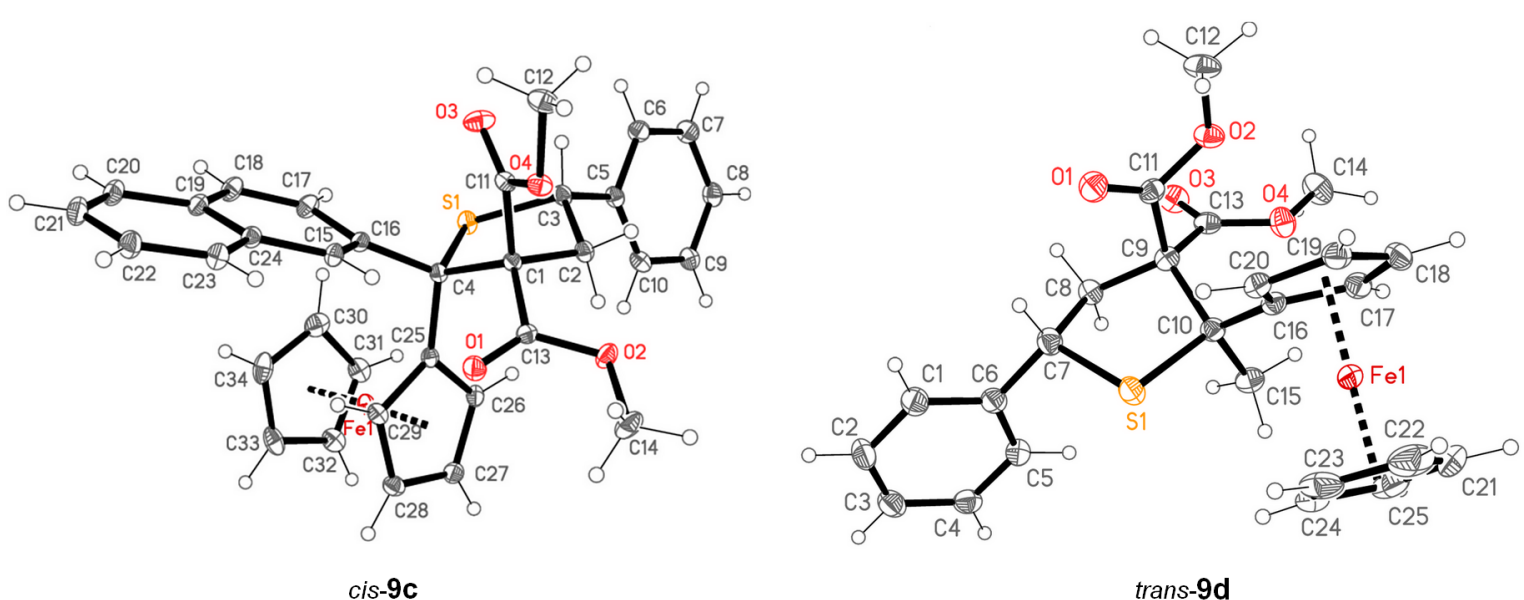

trans-9d 


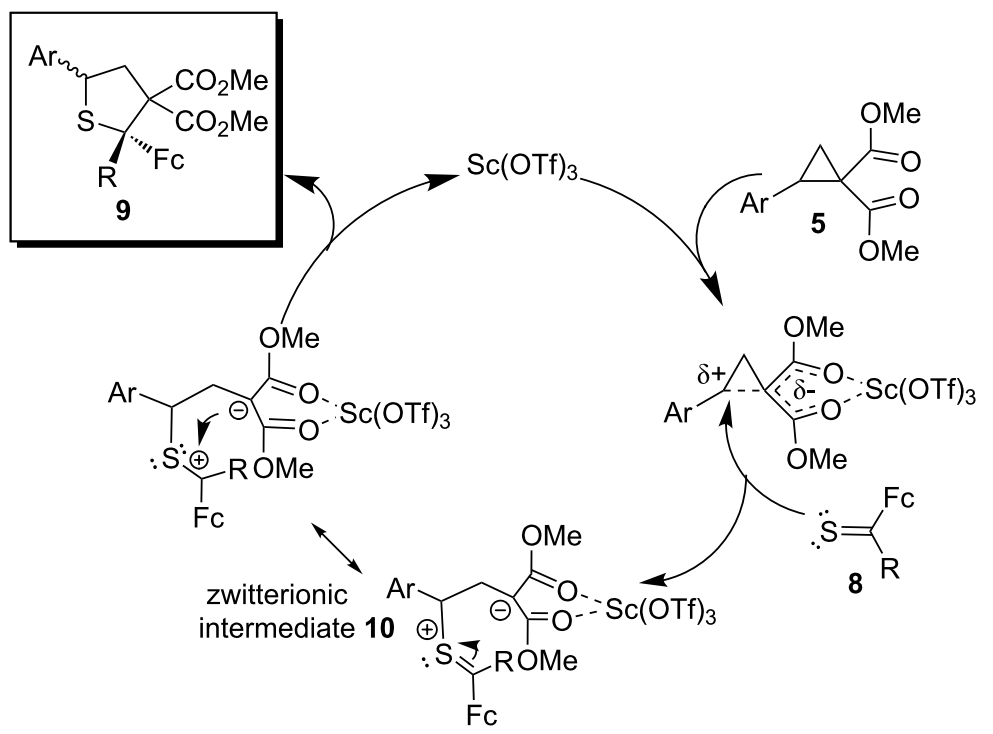

Scheme 4: Plausible mechanism for the formal [3+2]-cycloadditions of ferrocenyl thioketones 8 with D-A cyclopropanes 5

3-thioxo-2,2,4,4-tetramethylcyclobutanone with D-A cyclopropanes [21].

\section{Conclusion}

The present study showed once more that ferrocenyl/aryl and ferrocenyl/alkyl thioketones $\mathbf{8}$ are versatile and useful building blocks for a simple and efficient preparation of ferrocenyl-functionalized five-membered sulfur heterocycles. They were shown to react easily with donor-acceptor (D-A) cyclopropanes in the presence of scandium triflate, $\mathrm{Sc}(\mathrm{OTf})_{3}$ as a catalyst, yielding highly functionalized tetrahydrothiophene derivatives of type $\mathbf{9}$. These formal $[3+2]$-cycloaddition reactions occurred via a nucleophilic attack of the sulfur atom on the activated cyclopropane ring at the most reactive benzylic position. The formation of the five-membered ring occurred regioselectively and the expected tetrahydrothiophene-3,3-carboxylates were the products. The studied reactions displayed an interesting stereoselectivity and, in the case of 2,5-diaryl-substituted products 9 both aryl groups were exclusively located at the opposite sides of the ring plane. The described reactions supplement the recently reported synthetic applications of alkyl/ferrocenyl thioketones as attractive substrates for the synthesis of chiral ferrocene derivatives [22] and ferrocenyl-substituted platinathiiranes [23].

It should be also emphasized that the present study also demonstrated the growing potential of donor-acceptor cyclopropanes [24-28] as unique building blocks for current organic synthesis and especially for the efficient and highly stereoselective preparation of the relevant five-membered sulfur heterocycles derived from tetrahydrothiophene.

\section{Experimental}

General information: Solvents and chemicals were purchased and used as received without further purification. Products were purified by standard column chromatography on silica gel. Yields refer to analytically pure samples. NMR spectra were recorded with a Bruker Avance III $600 \mathrm{MHz}$ instrument $\left({ }^{1} \mathrm{H}\right.$ NMR: $600 \mathrm{MHz} ;{ }^{13} \mathrm{C}$ NMR: $\left.151 \mathrm{MHz}\right)$. Chemical shifts are reported relative to solvent residual peaks $\left({ }^{1} \mathrm{H}\right.$ NMR: $\delta=$ $\left.7.26 \mathrm{ppm}\left[\mathrm{CHCl}_{3}\right] ;{ }^{13} \mathrm{C} \mathrm{NMR}: \delta=77.0 \mathrm{ppm}\left[\mathrm{CDCl}_{3}\right]\right)$. IR spectra were recorded with a Cary 630 FTIR (Agilent Technologies) spectrometer (as film). Melting points were determined in capillaries with a Melt Temp II apparatus.

Starting materials: D-A cyclopropanes 5a-g were obtained following the reported procedure [28]. Ferrocenyl thioketones $8 \mathbf{a}-\mathbf{g}$ were obtained by thionation of corresponding ferrocenyl ketones [29] by treatment with Lawesson's reagent [30]. Ferrocenyl $\beta$-naphthyl thioketone (8b) obtained from ferrocenyl( $\beta$ naphthyl) ketone [31] is reported for the first time (see Supporting Information File 1).

General procedure: A solution of $0.3 \mathrm{mmol}$ of the corresponding cyclopropane 5 in $5 \mathrm{~mL}$ of dichloromethane was stirred for $5 \mathrm{~min}$. Then, $0.5 \mathrm{mmol}$ of the corresponding ferrocenyl thioketone 8 and a catalytic amount (ca. $5 \mathrm{mg}$ ) of $\mathrm{Sc}(\mathrm{OTf})_{3}$ was added to the stirred solution. The mixture was stirred at room temperature for $1 \mathrm{~h}$. The progress of the reaction was monitored by TLC. The solvent was evaporated in vacuo and the crude mixture was purified by flash chromatography using dichloromethane as the eluent. Analytically pure samples of tetrahydrothiophenes $\mathbf{9}$ were obtained by crystallization from 
petroleum ether or hexane with a small amount of dichloromethane.

The diastereoselectivity of the studied reactions was determined by integration of the crude ${ }^{1} \mathrm{H}$ NMR. Preliminary purification of crude mixtures by a short-column chromatography was necessary to remove traces of iron particles formed as a side product after partial decomposition of ferrocenyl containing substrates and/or products formed under reaction conditions

Dimethyl 2-ferrocenyl-2,5-diphenyltetrahydrothiophene3,3-dicarboxylate (cis-9a): Yield: $159 \mathrm{mg}$ (98\%); red crystals; mp $192-193^{\circ} \mathrm{C}$; ${ }^{1} \mathrm{H}$ NMR $\delta 2.65\left(\mathrm{dd}, J_{\mathrm{H}, \mathrm{H}}=13.9 \mathrm{~Hz}, J_{\mathrm{H}, \mathrm{H}}=\right.$ $4.3 \mathrm{~Hz}, 1 \mathrm{H}, \mathrm{HC}(4)), 3.44\left(\mathrm{~s}, 3 \mathrm{H}, \mathrm{OCH}_{3}\right), 3.46\left(\mathrm{~s}, 3 \mathrm{H}, \mathrm{OCH}_{3}\right)$, $3.56\left(\mathrm{dd}, J_{\mathrm{H}, \mathrm{H}}=13.9 \mathrm{~Hz}, J_{\mathrm{H}, \mathrm{H}}=12.7 \mathrm{~Hz}, 1 \mathrm{H}, H \mathrm{C}(4)\right)$, 3.51-3.60 (m, 1H, HC(Fc)), 4.00-4.02 (m, 1HC(Fc)), $4.07(\mathrm{~s}$, $5 H \mathrm{C}(\mathrm{Fc})), 4.27-4.29(\mathrm{~m}, 1 H \mathrm{C}(\mathrm{Fc})), 4.68-4.70(\mathrm{~m}, 1 \mathrm{HC}(\mathrm{Fc}))$, $4.81\left(\mathrm{dd}, J_{\mathrm{H}, \mathrm{H}}=12.6 \mathrm{~Hz}, J_{\mathrm{H}, \mathrm{H}}=4.3 \mathrm{~Hz}, H \mathrm{C}(5)\right), 7.31-7.39(\mathrm{~m}$, 2 arom. $H C), 7.40-7.46(\mathrm{~m}, 4$ arom. $H \mathrm{C}), 7.62-7.65(\mathrm{~m}, 2$ arom. $H \mathrm{C}), 8.21-8.24$ (m, 2 arom. $H \mathrm{C}) ;{ }^{13} \mathrm{C}$ NMR $\delta(\mathrm{C}(4)$-not found), 48.1, $48.4\left(2 \mathrm{OCH}_{3}\right), 52.4(\mathrm{C}(5)), 67.8(\mathrm{C}(2)), 71.1$ $(\mathrm{C}(3))$, 68.7, 69.2, 69.9, 71.0, 73.7 (for $9 \mathrm{HC}(\mathrm{Fc})), 97.0(C(\mathrm{Fc}))$, 126.6, 127.1, 127.9, 128.0, 128.8, 129.0 (for 10 arom. HC), 138.9, 144.2 (2 arom. $C), 169.0,170.3(2 C=\mathrm{O})$; IR $\left(\mathrm{cm}^{-1}\right)$ v: 1737 brs $(2 \mathrm{C}=\mathrm{O}), 1492 \mathrm{~m}, 1444 \mathrm{~m}, 1429 \mathrm{~m}, 1258 \mathrm{~m}, 1239 \mathrm{~s}$, $1073 \mathrm{~m}, 814 \mathrm{~m}, 760 \mathrm{~m}, 697 \mathrm{vs}, 497 \mathrm{vs}$; Anal. calcd for $\mathrm{C}_{30} \mathrm{H}_{28} \mathrm{FeO}_{4} \mathrm{~S}$ (540.45): C, 66.67; H, 5.22; S, 5.93; found: $\mathrm{C}$, 66.58; H, 5.24; S, 5.99.

Dimethyl 2,2-diferrocenyl-5-phenyl tetrahydrothiophene3,3-dicarboxylate (9b): Yield: $54 \mathrm{mg}$ (28\%); red crystals; mp $170{ }^{\circ} \mathrm{C}$ (dec.); ${ }^{1} \mathrm{H}$ NMR $\delta 2.91\left(\mathrm{dd}, J_{\mathrm{H}, \mathrm{H}}=14.0 \mathrm{~Hz}, J_{\mathrm{H}, \mathrm{H}}=\right.$ $6.2 \mathrm{~Hz}, 1 \mathrm{H}, H \mathrm{C}(4)), 3.36\left(\mathrm{~s}, 3 \mathrm{H}, \mathrm{OCH}_{3}\right), 3.41\left(\mathrm{dd}, J_{\mathrm{H}, \mathrm{H}}=\right.$ $\left.15.8 \mathrm{~Hz}, J_{\mathrm{H}, \mathrm{H}}=12.4 \mathrm{~Hz}, 1 \mathrm{H}, H \mathrm{C}(4)\right), 3.65\left(\mathrm{~s}, 3 \mathrm{H}, \mathrm{OCH}_{3}\right)$, 4.05-4.07 (m, 1H, HC(Fc)), 4.07-4.09 (m, 1H, HC(Fc)), 4.16-4.18 (m, 1H, HC(Fc)), 4.23-4.27 (m, 7H, 7HC(Fc)), 4.31 (s, 5H, $H \mathrm{C}(\mathrm{Fc})), 4.48-4.50(\mathrm{~m}, 1 \mathrm{H}, H \mathrm{C}(\mathrm{Fc})), 4.56-4.58(\mathrm{~m}, 1 \mathrm{H}$, $H \mathrm{C}(\mathrm{Fc})), 4.68-4.70(\mathrm{~m}, 1 \mathrm{H}, H \mathrm{C}(\mathrm{Fc})), 5.51\left(\mathrm{dd}, J_{\mathrm{H}, \mathrm{H}}=11.2 \mathrm{~Hz}\right.$, $\left.J_{\mathrm{H}, \mathrm{H}}=6.3 \mathrm{~Hz}, 1 \mathrm{H}, H \mathrm{C}(5)\right), 7.34-7.37$ (m, 1arom. $\left.H \mathrm{C}\right)$, 7.44-7.48 (m, 2arom. HC), 7.78 (m, 2arom. HC); ${ }^{13} \mathrm{C}$ NMR $\delta$ $47.9(\mathrm{C}(4)), 49.5(\mathrm{C}(5)), 51.9,52.6\left(2 \mathrm{OCH}_{3}\right), 65.8,66.2,66.9$, 67.6, 67.7, 69.6, 69.7, 70.4, 73.1 (for $18 \mathrm{HC}(\mathrm{Fc})$, 73.4, 94.3 $(\mathrm{C}(2)$ and $\mathrm{C}(3), 100.0(2 C(\mathrm{Fc})), 127.4,128.2,128.6$ (5 arom. HC), 141.2 (arom. C), 169.0, 169.1 (2 $C=\mathrm{O})$; IR $\left(\mathrm{cm}^{-1}\right)$ v: 1727 brs $(2 \mathrm{C}=\mathrm{O}), 1431 \mathrm{~m}, 1259 \mathrm{~s}, 1164 \mathrm{~s}, 1107 \mathrm{~m}, 1000 \mathrm{~m}, 818 \mathrm{~s}$, $760 \mathrm{~m}, 696 \mathrm{~s}, 479$ vs; anal. calcd for $\mathrm{C}_{34} \mathrm{H}_{32} \mathrm{Fe}_{2} \mathrm{O}_{4} \mathrm{~S}$ (648.37): C, 62.98; H, 4.97; S, 4.94; found: C, 62.68; H, 4.93; S, 4.88 .

Dimethyl 2-ferrocenyl-5-phenyl-2-(naphth-2-yl)tetrahydrothiophene-3,3-di-carboxylate (cis-9c): Yield: $115 \mathrm{mg}$ (65\%); yellow crystals; $\mathrm{mp} 210-211^{\circ} \mathrm{C}$; single crystals were obtained from hexane solution by slow evaporation at $\mathrm{rt} ;{ }^{1} \mathrm{H}$ NMR $\delta 2.69$ $\left(\mathrm{dd}, J_{\mathrm{H}, \mathrm{H}}=13.8 \mathrm{~Hz}, J_{\mathrm{H}, \mathrm{H}}=4.3 \mathrm{~Hz}, 1 \mathrm{H}, H \mathrm{C}(4)\right), 3.41(\mathrm{~s}, 3 \mathrm{H}$, $\left.\mathrm{OCH}_{3}\right), 3.47\left(\mathrm{~s}, 3 \mathrm{H}, \mathrm{OCH}_{3}\right), 3.57(\mathrm{~s}, 1 \mathrm{H}, H \mathrm{C}(\mathrm{Fc})), 3.62\left(\mathrm{t}, J_{\mathrm{H}, \mathrm{H}}\right.$ $=13.1 \mathrm{~Hz}, 1 \mathrm{H}, \mathrm{CH}), 4.01(\mathrm{~s}, 1 \mathrm{H}, H \mathrm{C}(\mathrm{Fc})), 4.09$ (s, $5 H \mathrm{C}(\mathrm{Fc}))$, $4.31(\mathrm{~s}, 1 \mathrm{H}, H \mathrm{C}(\mathrm{Fc})), 4.77(\mathrm{~s}, 1 \mathrm{H}, H \mathrm{C}(\mathrm{Fc})), 4.86\left(\mathrm{dd}, J_{\mathrm{H}, \mathrm{H}}=\right.$ $\left.12.6 \mathrm{~Hz}, J_{\mathrm{H}, \mathrm{H}}=4.3 \mathrm{~Hz}, 1 \mathrm{H}, H \mathrm{C}(5)\right), 7.36-7.40$ (m, 1 arom., HC), 7.44-7.48 (m, 2 arom. HC), 7.51-7.54 (m, 2 arom. HC), $7.66(\mathrm{~m}, 2$ arom. $H \mathrm{C}), 7.87\left(\mathrm{~d}, J_{\mathrm{H}, \mathrm{H}}=8.6 \mathrm{~Hz}, 1\right.$ arom., $\left.H \mathrm{C}\right)$, 7.88-7.92 (m, 1 arom., HC), 7.95-7.99 (m, 1 arom., HC), 8.36 $\left(\mathrm{d}, J_{\mathrm{H}, \mathrm{H}}=8.6 \mathrm{~Hz}, 1\right.$ arom., $\left.H \mathrm{C}\right), 8.74$ (s, 1 arom., $\left.H \mathrm{C}\right) ;{ }^{13} \mathrm{C}$ NMR $\delta 48.1(\mathrm{C}(5)), 48.5(\mathrm{C}(4)), 52.5,52.6\left(2 \mathrm{OCH}_{3}\right), 67.8$, 68.7, 69.2, 69.9, 71.2 (for $9 \mathrm{HC}(\mathrm{Fc})$ ), 71.0, $73.5(\mathrm{C}(2)$ and $\mathrm{C}(3)$ ) $97.4(2 \mathrm{C}(\mathrm{Fc})), 125.8,125.9,126.1,127.2,127.3,127.9,128.0$, 128.1, 128.6, 128.8 (10 arom. HC), 132.1, 132.8, 138.8, 141.8 (4 arom. C), 168.9, $170.3(2 C=\mathrm{O})$; IR $\left(\mathrm{cm}^{-1}\right)$ v: $1738 \mathrm{brs}$ $(2 \mathrm{C}=\mathrm{O}), 1429 \mathrm{~m}, 1239 \mathrm{~s}, 1215 \mathrm{~s}, 1170 \mathrm{~m}, 1053 \mathrm{~m}, 810 \mathrm{~s}, 758$ $\mathrm{m}, 704 \mathrm{~s}, 480 \mathrm{vs}$; anal. calcd for $\mathrm{C}_{34} \mathrm{H}_{30} \mathrm{FeO}_{4} \mathrm{~S}$ (590.51): C, 69.15; H, 5.12; S, 5.43; found: C, 67.16; H, 5.01; S, 5.47 .

Dimethyl 2-ferrocenyl-2-phenyl-5-methyltetrahydrothiophene-3,3-dicarboxylate (9d). Obtained as a 55:45 mixture of isomers. The trans- (major) and cis- (minor) isomers ( $\mathrm{Ph}$ to $\mathrm{Fc}$ ) were separated by PLC (silica, PE/ethyl acetate). Yields: cisisomer, yellow crystals, $66 \mathrm{mg}$ (more polar fraction, 44\%); mp 148-150 ${ }^{\circ} \mathrm{C}$, trans-isomer, yellow crystals, $74 \mathrm{mg}$ (less polar fraction, $54 \%$ ); mp $126-128{ }^{\circ} \mathrm{C}$; single crystals of trans-9d were obtained from hexane/ $\mathrm{CH}_{2} \mathrm{Cl}_{2}$ solution by slow evaporation at rt; ${ }^{1} \mathrm{H}$ NMR (cis-9d) $\delta 2.31\left(\mathrm{~s}, 3 \mathrm{H}, \mathrm{CH}_{3}\right) ; 2.54$ (dd, $J_{\mathrm{H}, \mathrm{H}}$ $\left.=13.8 \mathrm{~Hz}, J_{\mathrm{H}, \mathrm{H}}=5.3 \mathrm{~Hz}, 1 \mathrm{H}, H \mathrm{C}(4)\right) ; 3.22\left(\mathrm{dd}, J_{\mathrm{H}, \mathrm{H}}=13.8 \mathrm{~Hz}\right.$, $\left.J_{\mathrm{H}, \mathrm{H}}=12.3 \mathrm{~Hz}, 1 \mathrm{H}, H \mathrm{C}(4)\right) ; 3.46\left(\mathrm{~s}, 3 \mathrm{H}, \mathrm{OCH}_{3}\right) ; 3.80(\mathrm{~s}, 3 \mathrm{H}$, $\left.\mathrm{OCH}_{3}\right)$; 4.09-4.10 (m, 1H, $\left.\mathrm{HC}(\mathrm{Fc})\right) ; 4.12-4.13(\mathrm{~m}, 1 \mathrm{H}$, $H \mathrm{C}(\mathrm{Fc})$ ); 4.22 (s, 5H, $\mathrm{HCH}(\mathrm{Fc})) ; 4.23-4.25(\mathrm{~m}, 1 \mathrm{H}, H \mathrm{C}(\mathrm{Fc})$ ); $4.55-4.56(m, 1 \mathrm{H}, \mathrm{HC}(\mathrm{Fc})) ; 4.78\left(\mathrm{dd}, J_{\mathrm{H}, \mathrm{H}}=12.3 \mathrm{~Hz}, J_{\mathrm{H}, \mathrm{H}}=\right.$ $5.3 \mathrm{~Hz}, 1 \mathrm{H}, H \mathrm{C}(5)) ; 7.30-7.34$ (m, 1 arom. HC); 7.39-7.43 (m, 2 arom. $H \mathrm{C}) ; 7.54-7.58$ (m, 2 arom. $H \mathrm{C}) ;{ }^{13} \mathrm{C} \mathrm{NMR} \mathrm{(cis-9d)} \delta$ $25.9\left(\mathrm{CH}_{3}\right) ; 43.9(\mathrm{C}(4)) ; 47.9(\mathrm{C}(5)) ; 52.0,52.6\left(2 \mathrm{OCH}_{3}\right) ; 60.0$ $(\mathrm{C}(2))$; 68.1, 68.2, 68.8, 69.1, 70.7 (for $9 \mathrm{HC}(\mathrm{Fc})$ ); $70.6(\mathrm{C}(3)$ ); $96.5(C(\mathrm{Fc})) ; 127.5,127.6,128.7$ (5 arom. HC); 140.0 (arom. C); 168.5, $169.7(2 C=\mathrm{O})$; IR $\left(\mathrm{cm}^{-1}\right)$ v: 1731 brvs $(2 \mathrm{C}=\mathrm{O}) ; 1494$ m, 1453 m, 1436 m, 1248 vs, 1207 m, 1157 vs, 1105 m, 1038 s, 829 m, 766 s, 702 vs; anal. calcd for $\mathrm{C}_{25} \mathrm{H}_{26} \mathrm{FeO}_{4} \mathrm{~S}$ (478.38): $\mathrm{C}$, 62.77; H, 5.48; S, 6.70; found: C, 62.69; H, 5.52; S, 6.63.

${ }^{1} \mathrm{H}$ NMR (trans-9d) $\delta 2.28\left(\mathrm{~s}, 3 \mathrm{H}, \mathrm{CH}_{3}\right) ; 2.79\left(\mathrm{dd}, J_{\mathrm{H}, \mathrm{H}}=14.1\right.$ $\left.\mathrm{Hz}, J_{\mathrm{H}, \mathrm{H}}=10.7 \mathrm{~Hz}, 1 \mathrm{H}, H \mathrm{C}(4)\right) ; 3.12\left(\mathrm{dd}, J_{\mathrm{H}, \mathrm{H}}=14.1 \mathrm{~Hz}, J_{\mathrm{H}, \mathrm{H}}\right.$ $=7.1 \mathrm{~Hz}, 1 \mathrm{H}, \mathrm{HC}(4)) ; 3.47\left(\mathrm{~s}, 3 \mathrm{H}, \mathrm{OCH}_{3}\right) ; 3.66\left(\mathrm{~s}, 3 \mathrm{H}, \mathrm{OCH}_{3}\right)$; 4.19-4.21 (m, 2H, HC(Fc)); 4.23 (s, 5H, 5HC(Fc)); 4.40-4.42 $(\mathrm{m}, 1 \mathrm{H}, H \mathrm{C}(\mathrm{Fc})) ; 4.56-4.57(\mathrm{~m}, 1 \mathrm{H}, H \mathrm{C}(\mathrm{Fc})) ; 5.28\left(\mathrm{dd}, J_{\mathrm{H}, \mathrm{H}}=\right.$ $\left.10.7 \mathrm{~Hz}, J_{\mathrm{H}, \mathrm{H}}=7.1 \mathrm{~Hz}, 1 \mathrm{H}, H \mathrm{C}(5)\right) ; 7.30-7.32$ (m, 1 arom. HC); 7.39-7.42 (m, 2 arom. HC); 7.57-7.59 (m, 2 arom. HC); 
${ }^{13} \mathrm{C}$ NMR (trans-9d) $\delta 31.3\left(\mathrm{CH}_{3}\right) ; 47.1(\mathrm{C}(4)) ; 48.6(\mathrm{C}(5))$; 52.2, $52.3\left(2 \mathrm{OCH}_{3}\right) ; 60.1(\mathrm{C}(2)) ; 67.6(\mathrm{C}(3)) ; 68.5,68.8,69.1$, 69.3, 71.1 (for $9 \mathrm{HC}(\mathrm{Fc})$ ); $89.9(C(\mathrm{Fc})) ; 127.3,127.9,128.6(5$ arom. $\mathrm{HC}$ ); 142.6 (arom. $C$ ); 168.9, $169.5(2 C=\mathrm{O}) ; \mathrm{IR}\left(\mathrm{cm}^{-1}\right)$ v: 1737 vs, 1720 vs $(2 \mathrm{C}=\mathrm{O})$; $1492 \mathrm{~m}, 1453 \mathrm{~m}, 1427 \mathrm{~m}, 1258$ vs, 1220 s, 1204 m, 1106 m, 1105 m, 1023 m, 993 m, 829 m, 766 s, 703 vs; anal. calcd for $\mathrm{C}_{25} \mathrm{H}_{26} \mathrm{FeO}_{4} \mathrm{~S}$ (478.38): C, 62.77; $\mathrm{H}$, 5.48; S, 6.70; found: C, 62.70; H, 5.46; S, 6.59.

Dimethyl 2-ferrocenyl-5-phenyl-2-(thien-2-yl)tetrahydrothiophene-3,3-dicarboxy-late (trans-9l): Yield: $95 \mathrm{mg}$ (58\%); yellow crystals; mp $210{ }^{\circ} \mathrm{C}$ (dec.); ${ }^{1} \mathrm{H}$ NMR $\delta 2.65\left(\mathrm{dd}, J_{\mathrm{H}, \mathrm{H}}=\right.$ $\left.14.0 \mathrm{~Hz}, J_{\mathrm{H}, \mathrm{H}}=4.5 \mathrm{~Hz}, 1 \mathrm{H}, H \mathrm{C}(4)\right), 3.43$ (pseudo-t, $J_{\mathrm{H}, \mathrm{H}}=$ $13.9 \mathrm{~Hz}, 1 \mathrm{H}, H \mathrm{C}(4)), 3.48\left(\mathrm{~s}, 3 \mathrm{H}, \mathrm{OCH}_{3}\right), 3.52\left(\mathrm{~s}, 3 \mathrm{H}, \mathrm{OCH}_{3}\right)$, $4.10(\mathrm{~s}, 5 \mathrm{H}, 5 H \mathrm{C}(\mathrm{Fc})), 4.14(\mathrm{~s}, 2 \mathrm{H}, 2 \mathrm{HC}(\mathrm{Fc})), 4.30(\mathrm{~s}, 1 \mathrm{H}$, $H \mathrm{C}(\mathrm{Fc})), 4.68(\mathrm{~s}, 1 \mathrm{H}, \mathrm{HC}(\mathrm{Fc})), 5.02\left(\mathrm{dd}, J_{\mathrm{H}, \mathrm{H}}=13.6 \mathrm{~Hz}, J_{\mathrm{H}, \mathrm{H}}=\right.$ $4.5 \mathrm{~Hz}, 1 \mathrm{H}, H \mathrm{C}(5))$, 7.05-7.07 (m, 1 arom. HC), 7.21-7.23 (m, 1 arom. $H C), 7.34-7.38$ (m, 1 arom. $H C), 7.42-7.45(\mathrm{~m}, 2$ arom., $H \mathrm{C}$ ), 7.55-7.57 (m, 1 arom. $H \mathrm{C}), 7.60-7.63$ (m, 2 arom. $H \mathrm{C}) ;{ }^{13} \mathrm{C}$ NMR $\delta 47.3(\mathrm{C}(4)), 49.0(\mathrm{C}(5)), 52.2,52,5\left(2 \mathrm{OCH}_{3}\right)$, 67.9, 69.0, 69.4, 70.4, 70.7 (for $9 \mathrm{HC}(\mathrm{Fc})$ ), 66.3, 74.2 (2 arom. C), $94.6(1 C(\mathrm{Fc})), 123.4,125,8,126.8,127.9,128.0,128.8$ (for 8 arom. HC), 138.7, 150.3 (2 arom. $C$ ), 168.4, 169.5 (2C=O); IR $\left(\mathrm{cm}^{-1}\right)$ v: 1733 brs $(2 \mathrm{C}=\mathrm{O}), 1427 \mathrm{~m}, 1235 \mathrm{~s}, 1146 \mathrm{~s}, 1045 \mathrm{~m}$, 1032 m, 818 m, 766 s, 691 vs, 506 m, 488 s; HRMS-EI $(\mathrm{m} / \mathrm{z}):[\mathrm{M}]^{+}$calcd. for $\left[\mathrm{C}_{28} \mathrm{H}_{26} \mathrm{FeO}_{4} \mathrm{~S}_{2}\right]^{+}, 546.0621$; found: 546.0629 .

\section{Supporting Information}

CCDC-1992864 and CCDC-1992865 contain the supplementary crystallographic data for this paper. These data can be obtained free of charge from the Cambridge Crystallographic Data Centre via http://www.ccdc.cam.ac.uk/structures.

\section{Supporting Information File 1}

Experimental data for selected compounds 9, details of the crystal structure determination, and the original ${ }^{1} \mathrm{H}$ and ${ }^{13} \mathrm{C}$ NMR spectra for all products.

[https://www.beilstein-journals.org/bjoc/content/ supplementary/1860-5397-16-109-S1.pdf]

\section{Acknowledgements}

G. M. thanks Professor Wolfgang Weigand (Jena) (Alexander von Humboldt Foundation grant 'Institutspartnerschaft (JenaŁódź 2018-2020)), Professor Heinz Heimgartner (Zurich) and Dr. Katarzyna Urbaniak (Łódź) for stimulating discussions on the chemistry of ferrocenyl thioketones.

\section{Funding}

D. B. W. thanks the European Union for an ERC Consolidator Grant (Project: GAINBYSTRAIN).

\section{ORCID ${ }^{\circledR}$ iDs}

Grzegorz Mlostoń - https://orcid.org/0000-0003-3631-3239 Mateusz Kowalczyk - https://orcid.org/0000-0002-8589-7704 André U. Augustin - https://orcid.org/0000-0002-6425-2843 Daniel B. Werz - https://orcid.org/0000-0002-3973-2212

\section{Preprint}

A non-peer-reviewed version of this article has been previously published as a preprint doi:10.3762/bxiv.2020.43.v1

\section{References}

1. Benetti, S.; De Risi, C.; Pollini, G. P.; Zanirato, V. Chem. Rev. 2012, 112, 2129-2163. doi:10.1021/cr200298b

2. De Clercq, P. J. Chem. Rev. 1997, 97, 1755-1792. doi:10.1021/cr950073e

3. Huisgen, R.; Fulka, C.; Kalwinsch, I.; Xingya, L.; Mloston, G.; Moran, J. R.; Pröbstl, A. Bull. Soc. Chim. Belg. 1984, 93, 511-532. doi:10.1002/bscb.19840930701

4. Mlostoń, G.; Heimgartner, H. Pol. J. Chem. 2000, 74, 1503-1532.

5. Mlostoń, G.; Heimgartner, H. In 1,3-Dipolar cycloaddition chemistry towards heterocycles and natural products; Padwa, A.; Pearson, W. H., Eds.; Wiley: New York,, 2002; pp 315-360. doi:10.1002/0471221902.ch5

6. Huisgen, R.; Mlostoń, G.; Giera, H.; Langhals, E. Tetrahedron 2002, 58, 507-519. doi:10.1016/s0040-4020(01)01147-4

7. Huisgen, R.; Mloston, G.; Langhals, E. J. Org. Chem. 1986, 51, 4085-4087. doi:10.1021/jo00371a039

8. Huisgen, R.; Mlostoń, G.; Langhals, E.; Oshima, T. Helv. Chim. Acta 2002, 85, 2668-2685. doi:10.1002/1522-2675(200209)85:9<2668::aid-hlca2668>3.0.co;2-3

9. Augustin, A. U.; Sensse, M.; Jones, P. G.; Werz, D. B. Angew. Chem., Int. Ed. 2017, 56, 14293-14296. doi:10.1002/anie.201708346

10. Augustin, A. U.; Merz, J. L.; Jones, P. G.; Mlostoń, G.; Werz, D. B. Org. Lett. 2019, 21, 9405-9409. doi:10.1021/acs.orglett.9b03623

11. Kowalski, K.; Karpowicz, R.; Mlostoń, G.; Miesel, D.; Hildebrandt, A.; Lang, H.; Czerwieniec, R.; Therrien, B. Dalton Trans. 2015, 44, 6268-6276. doi:10.1039/c5dt00246j

12. Hejmanowska, J.; Jasiński, M.; Mlostoń, G.; Albrecht, Ł. Eur. J. Org. Chem. 2017, 950-954. doi:10.1002/ejoc.201601307

13. Mlostoń, G.; Hamera-Fałdyga, R.; Linden, A.; Heimgartner, H. Beilstein J. Org. Chem. 2016, 12, 1421-1427. doi:10.3762/bjoc.12.136

14. Mlostoń, G.; Hamera-Fałdyga, R.; Jeske, M.; Godziszewska, M.; Urbaniak, K.; Heimgartner, H. J. Sulfur Chem. 2018, 39, 47-63. doi:10.1080/17415993.2017.1363206

15. Mlostoń, G.; Urbaniak, K.; Zimmer, R.; Reissig, H.-U.; Heimgartner, H. ChemistrySelect 2018, 3, 11724-11728. doi:10.1002/slct.201803096

16. Astruc, D. Eur. J. Inorg. Chem. 2017, 6-29. doi:10.1002/ejic.201600983

17. Heinze, K.; Lang, H. Organometallics 2013, 32, 5623-5625. doi:10.1021/om400962w

18. Mlostoń, G.; Hamera-Fałdyga, R.; Celeda, M.; Heimgartner, H. Org. Biomol. Chem. 2018, 16, 4350-4356. doi:10.1039/c8ob01022f 
19. Mloston, G.; Hamera-Fałdyga, R.; Heimgartner, H. J. Sulfur Chem. 2018, 38, 267-278. doi:10.1080/17415993.2017.1415339

20. Petzold, M.; Jones, P. G.; Werz, D. B. Angew. Chem., Int. Ed. 2019, 58, 6225-6229. doi:10.1002/anie.201814409

21. Augustin, A. U.; Busse, M.; Jones, P. G.; Werz, D. B. Org. Lett. 2018, 20, 820-823. doi:10.1021/acs.orglett.7b03961

22. Cai, Z.-J.; Liu, C.-X.; Wang, Q.; Gu, Q.; You, S.-L. Nat. Commun. 2019, 10, 4168. doi:10.1038/s41467-019-12181-x

23. Gröber, S.; Matczak, P.; Domagała, S.; Weisheit, T.; Görls, H.; Düver, A.; Mlostoń, G.; Weigand, W. Materials 2019, 12, 2832. doi:10.3390/ma12172832

24. Reissig, H.-U.; Zimmer, R. Chem. Rev. 2003, 103, 1151-1196. doi:10.1021/cr010016n

25. Schneider, T. F.; Kaschel, J.; Werz, D. B. Angew. Chem., Int. Ed. 2014, 53, 5504-5523. doi:10.1002/anie.201309886

26. Cavitt, M. A.; Phun, L. H.; France, S. Chem. Soc. Rev. 2014, 43, 804-818. doi:10.1039/c3cs60238a

27. Werz, D. B.; Biju, A. T. Angew. Chem., Int. Ed. 2020, 59, 3385-3398. doi:10.1002/anie.201909213

28. Kreft, A.; Lücht, A.; Grunenberg, J.; Jones, P. G.; Werz, D. B. Angew. Chem., Int. Ed. 2019, 58, 1955-1959. doi:10.1002/anie.201812880

29. Mlostoń, G.; Hamera, R.; Heimgartner, H. Phosphorus, Sulfur Silicon Relat. Elem. 2015, 190, 2125-2133. doi:10.1080/10426507.2015.1071817

30. Mlostoń, G.; Pipiak, P.; Heimgartner, H. Beilstein J. Org. Chem. 2016, 12, 716-724. doi:10.3762/bjoc.12.71

31. Rodriquez-Cendejas, C. D.; Liebeskind, L. S.; Peña-Cabrera, E. ARKIVOC 2005, No. vi, 250-265. doi:10.3998/ark.5550190.0006.621

\section{License and Terms}

This is an Open Access article under the terms of the Creative Commons Attribution License (http://creativecommons.org/licenses/by/4.0). Please note that the reuse, redistribution and reproduction in particular requires that the authors and source are credited.

The license is subject to the Beilstein Journal of Organic Chemistry terms and conditions:

(https://www.beilstein-journals.org/bjoc)

The definitive version of this article is the electronic one which can be found at: $\underline{\text { doi:10.3762/bjoc. } 16.109}$ 